\title{
Keefektifan Penggunaan Model Pembelajaran Learning Together (LT) dengan Paduan Model Talking Stick Materi SPLDV Siswa Kelas VIII SMP
}

\author{
Mira Mulasandi ${ }^{1}$, Dewi Pramita ${ }^{2}$ \\ ${ }^{1,2}$ Pendidikan Matematika, Universitas Muhammadiyah Mataram, \\ ${ }^{1}$ mira.ummat@gmail.com, ${ }^{2}$ mitha dhewi@yahoo.com
}

INFO ARTIKEL

Riwayat Artikel:

Diterima: 01-09-2017

Disetujui: 25-09-2017

\section{Kata Kunci:}

Learning Together Talking Stick SLPDV

\section{A. LATAR BELAKANG}

Pendidikan diartikan sebagai upaya peningkatan harkat dan martabat manusia serta dituntut untuk menghasilkan kualitas manusia yang lebih tinggi

\begin{abstract}
Abstrak: Tujuan Penelitian ini adalah untuk mengetahui keefektifan pembelajaran kooperatif tipe Learning together dengan paduan kooperatif tipe talking stick terhadap hasil belajar siswa pokok bahasan SPLDV pada siswa kelas VIII SMP N 19 Mataram tahun pelajaran 2015/2016. Jenis penelitian ini adalah penelitian eksperimen. Populasi dalam penelitian ini adalah siswa kelas VIII SMP N 19 Mataram yang terdiri dari empat kelas yang berjumlah 144 siswa dan diambil dua kelas sebagai sampel yaitu kelas VIII A (kelas kontrol) yang berjumlah 36 siswa yang akan diberlakukan model pembelajaran ekspositori serta kelas VIII B (kelas eksperimen) yang berjumlah 37 siswa akan diberlakukan model pembelajaran kooperatif tipe LT dengan paduan kooperatif tipe talking stick. Instrumen yang digunakan adalah tes uraian yang terdiri dari lima soal uraian. Hasil penelitian ini menunjukan bahwa nilai rata-rata posttest kelas VIII A sebesar 70,94 dan rata-rata posttest kelas VIII B sebesar 76,29. Uji normalitas data posttest kelas kontrol dan kelas eksperimen menggunakan rumus uji Chi kuadrat yang menunjukan $\boldsymbol{x}^{2}$ hitung kurang dari $\boldsymbol{x}^{2}$ tabel yang berarti data dinyatakan normal. Sedangkan uji homogenitas data menunjukan bahwa varians posttest kelas kontrol dan kelas eksperimen dinyatakan homogen dimana fhitung kurang dari fabel. Hasil uji-t diperoleh thitung 1,83 dan tabel 1,66 hal ini menunjukan hasil belajar matematika siswa yang menggunakan model pembelajaran kooperatif tipe LT dengan paduan kooperatif tipe talking stick lebih efektif dibandingkan dengan hasil belajar siswa yang menggunakan metode ekspositori pada pokok bahasan SPLDV siswa kelas VIII SMP N 19 Mataram tahun ajaran 2015/2016.
\end{abstract}

\begin{abstract}
The purpose of the research is to know how effective of cooperative learning together type with cooperative talking stick type to learning outcomes student about SPLDV in student grade 8 SMP N 19 Mataram academic year 2015/2016. This study was a experimental research. This research was conducted on Grade 8 SMP N 19 Mataram divided to four classroom with 144 student and the sample is student grade $8 \mathrm{~A}$ (control clasrooom) with 36 student was treatment with expository learning, and student grade $8 B$ (experimental classroom) was reatment with cooperative learning together and cooperative learning talking stick type. The research use written test with five question. Result of this research shown average value of posttest control classroom is 70,94 and posttest of experimental classroom is 76,29. Normality test of data reaserch in posttest control classroom and experimental classroom used chi square test are $x^{2}$ calculate less than $x^{2}$ table that mean data is normaly distributed. Homogenity test result in posttest control classroom and experimental classroom is $f_{\text {calculate }}$ less than $f_{\text {table. }}$. Result of $T$ test are $t_{\text {calculate }}$ 1,83 and table 1,66 its mean that the learning outcomes of student was reatment with cooperative learning together and cooperative learning talking stick type more effective than student was treatment with expository learning about SPLDV student grade 8 SMP N19 Mataram academic year 2015/2016.
\end{abstract}

guna menjamin pelaksanaan dan kelangsungan pembangunan. Peningkatan kualitas pendidikan harus dipenuhi melalui peningkatan kualitas dan kesejahteraan pendidik, dan tenaga kependidikan lainnya. Amri dalam Huda mengemukakan bahwa 
peran guru dalam aktifitas pembelajaran tidak hanya menyampaikan ilmu pengetahuan, tetapi juga memainkan berbagai peran yang bertujuan mengembangkan potensi siswa secara spiritual [1]. Ketika berencana memasukkan salah satu atau beberapa model ke dalam suatu program tertentu, guru seharusnya menggunakan kerangka-kerja kurikulum yang didalamnya berisi prinsip-prinsip pengajaran dan pembelajaran untuk membantu belajar siswa, serta penilaian atau assesement untuk melihat hasil akademik yang telah diperoleh siswa.

Untuk meningkatkan peran aktif siswa salah satunya melalui model pembelajaran kooperatif. Aktivitas pembelajaran kooperatif menekankan pada kesadaran siswa perlu belajar untuk mengaplikasikan pengetahuan, konsep, keterampilan kepada siswa yang membutuhkan atau anggota lain dalam kelompoknya, sehingga belajar kooperatif dapat saling menguntungkan antara siswa yang berprestasi rendah dan siswa yang berprestasi tinggi. Berdasarkan penelitian yang dilakukan Slavin datentang pengaruh pembelajaran kooperatif terhadap hasil belajar pada semua tingkat kelas dan semua bidang studi menunjukkan bahwa kelas kooperatif menunjukkan hasil belajar akademik yang signifikan lebih tinggi dibandingkan kelompok kontrol [2]. Adapun model pembelajaran kooperatif yaitu tipe LT dan Talking Stick. Pada penelitian ini peneliti memadukan dua model pembelajaran kooperatif tipeLT dan Talking Stick yang dapat dijadikan alternatif untuk meningkatkan peran aktif siswa yaitu dibentuk kelompok heterogen, setiap kelompok beranggotakan 4-5 siswa, pada kedua tipe kooperatif ini siswa dilatih untuk dapat bekerja sama, berani dan percaya diri untuk mempersentasikan hasil yang didapatkan oleh siswa dalam proses pengerjaaan kelompok, pada kelompok yang mendapatkan nilai tinggi akan diberikan penghargaan (reward). Sehingga cara ini menjamin keterlibatan total semua siswa dalam mengupayakan hasil yang baik untuk meningkatkan tanggung jawab individual dalam diskusi kelompok.

Berdasarkan uraian sebelumnya, maka peneliti mengadakan penelitian dengan judul "Keefektifan Penggunaan Model Pembelajaran Kooperatif Tipe LT dengan paduan kooperatif tipe Talking Stick pada Pokok Bahasan SPLDV Siswa Kelas VIII SMP N 19 Mataram Tahun Ajaran 2015/2016".

\section{B. METODE PENELITIAN}

\section{Rancangan Penelitian}

Penelitian ini menggunakan metode penelitian eksperimen dengan desain quasi experimental. Adapun tujuan dari penelitian ini adalah untuk menyelidiki adanya kemungkinan hubungan sebab akibat dengan cara menerapkan model pembelajaran kooperatif tipe LT dengan paduan kooperatif tipe Talking Stick pada kelompok eksperimen dan membandingkan hasilnya dengan menerapkan model pembelajaran ekspositori pada kelompok kontrol, kemudian pada kedua kelompok ini akan berikan tes akrir (posttest).

Lokasi penelitian bertempat di SMPN 19 Mataram. Waktu penelitian yaitu 13 November s/d 18 Desember tahun 2015. Populasi dalam penelitian ini adalah seluruh siswa kelas VIII, yang terdiri dari kelas VIII A, VIII B, VIII C, dan VIII D SMPN 19 Mataram tahun ajaran 2015/2016. Masing-masing kelas terdiri dari 36 siswa. Jadi, jumlah keseluruhan siswa adalah 144 siswa. Sampel dalam penelitian ini adalah kelas VIII A sebagai kelas kontrol dan kelas VIII B sebagai kelas eksprimen.

Adapun Instrument penelitian yang digunakan adalah tes. Tes dalam penelitian ini digunakan untuk mengetahui kemampuan pemahaman konsep matematika. Bentuk soal tes pada penelitian ini terdiri dari tes uraian objektif. Bentuk soal uraian objektif sangat tepat digunakan untuk bidang matematika dan sains, karena kunci jawabannya hanya satu dan dalam setiap pengerjaan melalui suatu prosedur atau langkah-langkah tertentu.

\section{Prosedur Penelitian}

Adapun prosedur penelitian yaitu:

a. tahap Persiapan

1) Membuat instrumen penelitian dan perangkat pembelajaran (RPP, LKS), dan Test.

2) Mengelompokkan sampel menjadi kelompok eksperimen dan kelompok kontrol, yaitu kelas VIII A sebagai kelas kontrol dan kelas VIII B sebagai kelas eksperimen.

3) Melakukan uji coba instrument test pada kelas VIII C.

b. Tahap pelaksanaan

Adapun tahap pelaksanaan meliputi: 
1) Memberikan perlakuan kepada kelas eksperimen berupa model pembelajaran kooperatif tipeLT dengan paduan kooperatif tipe Talking Stickdan memberikan perlakuan kepada kelas kontrol dengan model pembelajaran ekspositori.

2) Memberikan test akhir kepada kedua kelompok sampel.

c. Tahap akhir

1) Menganalisis data akhir.

2) Menyimpulkan data penelitian.

3) Membuat laporan hasil penelitian.

\section{Analisis Data}

Dalam melakukan analisis data, maka dilakukan: 1) uji instrumen penelitian yang meliputi uji validitas dan realibilitas. 2) Uji prasyarat analisis data, yang meliputi Uji homogenitas, Normalitas data, dan Uji hipotesis

\section{HASIL DAN PEMBAHASAN}

Dari pengamatan peneliti secara langsung dimana penelitian ini dimaksudkan untuk mengetahui keefektifan penggunaan model pembelajaran koooperatif tipe LT dengan paduan kooperatif tipe Talking Stick terhadap hasil belajar siswa, yaitu selama proses pembelajaran berlangsung siswa mengalami perubahan dalam proses pembelajaran dimana pada model pembelajaran sebelumnya siswa hanya pasif dan hanya mendengarkan materi dari guru namun setelah dilaksanakannya model pembelajaran koooperatif tipe LT dengan paduan kooperatif tipe Talking Stick siswa mengalami perubahan yaitu siswa mulai aktif bertanya dan mengemukakan pendapatnya kepada temannya yang dianggap salah dalam proses pengerjaan soal, siswa dalam satu kelompok saling membantu atau saling bertukar fikiran saat pengerjaan soal, siswa tidak merasa canggung bertanya kepada peneliti mengenai soal yang belum jelas, perubahan-perubahan siswa tersebut tidak berlangsung secara cepat, namun secara bertahap seiring dengan berlangsung model pembelajaran koooperatif tipe LT dengan paduan kooperatif tipe Talking Stick.

Keefektifan model pembelajaran koooperatif tipe LT dengan paduan kooperatif tipe Talking Stick memberikan hasil belajar kepada siswa dapat dilihat berdasarkan hasil pengolahan dan analisis data secara statistik hasil penelitian ini menunjukan bahwa nilai rata-rata posttest kelas VIII A sebagai kelas kontrol sebesar 70,94 dan rata-rata posttest kelas VIII B sebagai kelas eksperimen sebesar 76,29. Uji normalitas data posttest kelas kontrol dan kelas eksperimen menggunakan rumus uji Chi kuadrat yang menunjukan $x^{2}$ hitung kurang dari $x^{2}$ tabel yang berarti data dinyatakan normal. Sedangkan uji homogenitas data menunjukan bahwa varians posttest kelas kontrol dan kelas eksperimen dinyatakan homogen dimana $f_{\text {hitung }}$ kurang dari $f_{\text {tabel }}$. Hasil uji - $\mathrm{t}$ diperoleh $\mathrm{t}_{\text {hitung }} 1,83$ dan $\mathrm{t}_{\text {tabel }}$ 1,66 serta dari hipotesis yang diajukan maka hasil belajar matematika siswa yang menggunakan model pembelajaran kooperatif tipe LT dengan paduan kooperatif tipe Talking Stick lebih efektif dibandingkan dengan hasil belajar siswa yang menggunakan model pembelajaran ekspositori pada pokok bahasan SPLDV siswa kelas VIII SMP N 19 Mataram tahun ajaran 2015/2016.

Berdasarkan hal-hal yang telah dikemukakan pada pembahasan dan hasil pengujian hipotesis dengan menggunakan uji-t yaitu $t_{\text {hitung }}=1,83>t_{\text {tabel }}=$ 1,66 , dengan taraf kesalahan $5 \%$. Karena $t_{\text {hitung }}$ lebih besar dari $t_{\text {tabel }}(1,83>1,66)$, maka dapat ditarik kesimpulan $\mathrm{H}_{\mathrm{o}}$ ditolak dan $\mathrm{H}_{\mathrm{a}}$ diterima (Hasil belajar matematika siswa yang menggunakan model pembelajaran kooperatif tipe LT dengan paduan kooperatife tipe Talking Stick lebih efektif dibandingkan dengan hasil belajar siswa yang menggunakan metode ekspositori. Artinya terdapat pengaruh penerapan model pembelajaran kooperatife LT dengan paduan kooperatife tipe Talking Stick terhadap hasil belajar siswa pada pokok bahasan SPLDV siswa kelas VIII SMP Negeri 19 Mataram tahun pelajaran 2015/2016.

\section{SIMPULAN DAN SARAN}

Berdasarkan hal-hal yang telah dikemukakan pada pembahasan dan hasil pengujian hipotesis dengan menggunakan uji-t yaitu $t_{\text {hitung }}=1,83>t_{\text {tabel }}=$ 1,66 , dengan taraf kesalahan $5 \%$. Karena $t_{\text {hitung }}$ lebih besar dari $t_{\text {tabel }}(1,83>1,66)$, maka dapat ditarik kesimpulan $\mathrm{H}_{\mathrm{o}}$ ditolak dan $\mathrm{H}_{\mathrm{a}}$ diterima (Hasil belajar matematika siswa yang menggunakan model pembelajaran kooperatif tipe LT dengan paduan kooperatife tipe Talking Stick lebih efektif dibandingkan dengan hasil belajar siswa yang menggunakan metode ekspositori. Artinya terdapat pengaruh penerapan model pembelajaran kooperatife LT dengan paduan kooperatife tipe 
Talking Stick terhadap hasil belajar siswa pada pokok bahasan SPLDV siswa kelas VIII SMP Negeri 19 Mataram tahun pelajaran 2015/2016.

Berdasarkan hasil penelitian yang telah dilakukan, penulis mengajukan beberapa saran, antara lain:

Siswa: Untuk meningkatkan pemahaman belajarnya, diharapkan agar siswa dapat belajar dengan seefisien mungkin di rumahnya. Misalnya dengan pembuatan jadwal belajar serta dilaksanakan dengan disiplin, mengulangi mempelajari materi yang telah diberikan, membaca atau membuat catatan, konsentrasi dan lain sebagainya.

Guru: Diharapkan agar guru khususnya guru mata ajaran matematika lebih memperhatikan kondisi baik itu kondisi lingkungan siswa, kondisi kurikulum yang diterapkan ataupun kondisi psikis siswa, apakah siswa telah mengalami proses belajar di luar jam sekolah atau di rumah dengan baik khususnya di dalam kelas.

Peneliti: Perlu adanya penelitian lebih lanjut tentang masalah yang sama karena karakteristik yang diungkap dalam penelitian ini sangat terbatas, sehingga apa yang menjadi rekomendasi nantinya dapat dijadikan sebagai pedoman yang dapat dipertanggungjawabkan kepada semua pihak yang terlibat dalam proses belajar mengajar.

\section{REFERENSI}

[1] Huda, Miftahul. (2013). Model-model Pembelajaran dan Pengajaran. Yogyakarta: Pustaka Pelajar

[2] Ibrahim, Muslimin, dkk. (2002). Pembelajaran Kooperatif. Surabaya: UNESA-University.

[3] LPPM UMMat. (2016). Pedoman Penelitian dan Pengabdian UMM. Mataram.

[4] Subana dan Sudrajat. (2001). Dasar-Dasar Penelitian Ilmiah. Bandung: Pustaka Setia.

[5] Sudjana. (2005). Metode Statistika. Bandung: Tarsito.

[6] Sugiyono. (2010). Metode Penelitian Pendidikan. Bandung: Alfabeta.

[7] Suharsimi. (2010). Prosedur Penelitian Suatu Pendekatan Praktik. Jakarta: PT. Rineka Cipta. 